М.В. Науменко

Харківський національний університет Повітряних Сил ім. I. Кожедуба, Харків

\title{
МЕТОДИЧНИЙ ПІДХІД ДО ОЦІНЮВАННЯ МОЖЛИВОСТІ РЕАЛІЗАЦІЇ ПРОГРАМИ ОНОВЛЕННЯ ПАРКУ ЛІТАКІВ ТАКТИЧНОЇ АВІАЦІЇ НА ЕТАПІ ІІІ СИНТЕЗУ ПРИ ОБМЕЖЕНИХ ФІНАНСОВИХ СПРОМОЖНОСТЯХ ДЕРЖАВ
}

Запропоновано методичний підхід до кількісного очінювання балансу між потрібними витратами ресурсів та наявними в державі фінансовими ресурсами, щяо можуть бути виділені для реалізації синтезованих варіантів програми розвитку системи озбросння та військової техніки тактичної авіації на середньота довгостроковій перспективі. Даний методичний підхід, в залежності від варіанту обрання стратегії розвитку системи озброєння тактичної авіаџї̈, призначений для очінювання можливості реалізаџії раџіонального варіанту програми, синтезованого на основі розв'язування математичної задачі оптимізаиії в зворотній постановці, а також для формування елементів системи обмежень у формалізованому критерії рациіональності при обранні стратегії розвитку парків літаків тактичної авіації по набуттю нею необхідних спроможностей за мінімально можливий час та у формалізованому критерії раціональності - при виборі стратегії по максимальному нарощенню спроможностей тактичною авіацією при обмеженому фінансуванні розвитку ї̈ системи озброєння та військової техніки. Оскільки фінансування програми переозброєння тактичної авіаиії, найімовірніше, буде здійснюватися коштом Державного бюджету Украӥни, у запропонованому методичному підході до оцінювання можливості реалізації такої програми пропонується спиратися на нормативно-правову базу Украӥни, що регламентує обсяги фінансування Сектору безпеки $i$ оборони, та статистичні дані щзодо наявного розподілу коштів на потреби Збройних Сил України за видами та напрямками фінансування, а також на результати аналізу світового досвіду фінансування такого роду програм. Прогноз фінансових показників на заданій глибині планування розвитку системи озброєння та військової техніки тактичної авіації, що характеризують обсяги иільового фінансування витрат на розвиток, закупівлю, модернізаиію та ремонт озброєння, військової техніки, засобів та обладнання пропонується будувати на використанні статистичного матеріалу щодо фінансування переозбросння тактичної авіації, накопиченого у ретроспективі, та даних прогнозу Світового банку щодо росту ВВП України на середньо- та довгостроковій перспективі. Виявлення на етапі синтезу невідповідності потрібного фінансового ресурсу тому, який очікувано зможе бути забезпечено державним фінансуванням, надає можливості для своєчасного пошуку альтернативних шляхів набуття необхідних спроможностей або додаткових джерел фінансування, що сприятиме запобіганню зайвим витратам ресурсів та часу для набуття необхідного рівня спроможностей тактичною авіаиією.

Ключові слова: тактична авіачія, стратегія розвитку, фінансування, прогноз.

\section{Вступ}

Прийняття управлінських рішень щодо розвитку системи озброєння та військової техніки (ОВТ) тактичної авіації в межах оборонного планування на основі спроможностей, має за мету набуття необхідних спроможностей тактичною авіацією у виконанні покладених завдань відповідно до визначених сценаріїв застосування Повітряних Сил (ПС) Збройних Сил (3С) України у визначені терміни за умови ефективного використання наявного (запланованого) фінансового ресурсу, виділеного саме на це цільове призначення [1-4].

Відповідно до реалізації основних процедур оборонного планування документами $[1 ; 4]$ визначені заходи, що проводяться на етапі планування сил та формування варіантів перспективного бойового складу для набуття мінімально необхідних спроможностей військ, зокрема тактичної авіації, розвиток яких має бути державою гарантовано забезпеченим ресурсами. У зв'язку з цим, в межах прийнятої процедури оборонного планування на основі спроможностей передбачається проведення досліджень щодо оцінювання обсягів необхідного фінансового ресурсу для їх набуття. Але крім цього, водночас, необхідним $€$ проведення оцінювання відповідності визначених для альтернативних варіантів складу сил обсягів необхідних ресурсів тим, яких держава в змозі буде виділити на набуття тактичною авіацією необхідних спроможностей у виконанні всіх бойових (оперативних) завдань, що покладатимуться на неї, відповідно до визначених сценаріїв застосування. Цей аспект може стати критичним з точки зору можливості реалізації розроблених програм і планів 
набуття необхідних спроможностей, та постати гострою проблемою у забезпеченні балансу між вартістю набуття необхідних спроможностей і фінансовоекономічними можливостями держави. Такий баланс може розглядатися як потенційний компроміс між визначеним необхідним обсягом фінансування для повної реалізації необхідних спроможностей та можливостями економіки держави.

Таким чином, не врахування на етапі синтезу самої програми розвитку системи ОВТ тактичної авіації результатів досліджень щодо оцінювання адекватності фінансових показників набуття необхідних спроможностей економічним можливостям держави, може призвести до виникнення суттєвих ризиків стосовно неможливості реалізації набуття необхідних спроможностей, або обумовить необхідність термінового пошуку шляхів усунення невідповідності фінансування програми вже на етапі ii реалізації. До речі, такими шляхами можуть бути варіанти додаткового фінансування як за рахунок Державного бюджету України, так і за рахунок міжнародної допомоги, або перерозподіл наявного фінансового ресурсу за часом, або іншими суб'єктами фінансування.

Аналіз останніх досліджень і публікацій. Як свідчить огляд доступних джерел інформації [5-13], в існуючих методичних підходах, що застосовуються на етапі формування програм і планів розвитку тактичної авіації, зазвичай робиться акцент на оцінювання раціональності іiі кількісно-якісного складу, який має бути досягнутий наприкінці терміну планування [14]. Більшість 3 відомих методичних підходів грунтується на використанні експертних методів оцінювання або проведенні SWOT аналізу, як оперативного середовища, в якому в перспективі буде функціонувати перспективна тактична авіація, так і варіантів побудови відповідної ії системи озброєння, а також перспектив реалізації програмних і планових заходів щодо розвитку такої системи OBT [6-10; 14]. Такі підходи, нажаль, не дають можливості отримання адекватного кількісного оцінювання можливості реалізації синтезованих варіантів програми 3 урахуванням обсягів ii фінансування на всій глибині планування, а також не забезпечують визначення у кількісному вимірі ступеню невідповідності необхідного фінансування наявним економічним спроможностям держави. При цьому, наявність результатів вищеназваного оцінювання сприяло б своєчасному пошуку альтернативних шляхів набуття необхідних спроможностей або додаткових джерел фінансування, та запобігало б зайвим витратам ресурсів та часу для набуття необхідного рівня спроможностей тактичною авіацією.

Значна кількість наукових досліджень, що присвячені аналізу можливості реалізації програм розвитку систем ОВТ та управління ними на проміж- них етапах, такі як, наприклад [15-17], передбачають коригування вже синтезованих та прийнятих до реалізації програм у разі виникнення відхилень результатів виконання цих програм на окремих етапах від планів ефективного освоєння вже виділених ресурсів. В названих роботах навіть не розглядаються питання щодо створення методичного підходу до оцінювання відповідності наявних (або тих, що прогнозуються) економічних можливостей держави щодо фінансування як проміжних етапів програм, так і програми в цілому при синтезі таких програм й обгрунтуванні їх окремих показників. При цьому, оцінюється ефективність виконання програм розвитку систем ОВТ за показниками, які статистично відображають інформацію про результати та кількість виконаних заходів за плановий період й не ставлять за мету ефективний розподіл виділених коштів на наступні періоди реалізації програм (як правило, увага приділяється розгляду саме короткострокового періоду планування), а зводяться до констатації фактів кількості невиконаних заходів і ступеня неповноти та несвоєчасності фінансування програм розвитку 3С України [16-18]. Результати таких досліджень постфактум не є інформативними 3 точки зору своєчасності внесення завчасних коректив у програму, які б могли сприяти успішній реалізації програми.

Окремі дослідження [19-21] пропонують методичні підходи до можливості підвищення ефективності короткострокового планування та виконання заходів програм розвитку ЗС України із урахуванням результатів воєнно-економічного оцінювання результатів виконання комплексу заходів програм розвитку за минулий період, але не досліджується така можливість на середньо- та довгостроковій перспективі.

Слід зазначити, що наявна на сьогодні недосконалість науково-методичного апарату щодо оцінювання можливості реалізації програми розвитку системи ОВТ, зокрема, системи ОВТ тактичної авіаціï, на етапі іiі формування із урахуванням економічних можливостей держави, розглядається одним із ризиків для успішності всієї процедури планування ресурсів при реалізації основних концептів оборонного планування на основі спроможностей [2; 22-24].

Наведене вище свідчить про актуальність та практичну значущість проведення досліджень 3 удосконалення науково-методичного апарату оцінювання адекватності потреб в фінансових ресурсах для набуття необхідних спроможностей тактичною авіацією у виконанні бойових (оперативних) завдань за рахунок розвитку іï системи ОВТ економічним спроможностям держави на етапах синтезу програми оновлення парку бойової авіаційної техніки на середньо - і довгострокову перспективу. 
Таким чином, метою статті $\epsilon$ розробка методичного підходу до оцінювання на етапі синтезу програми розвитку системи ОВТ тактичної авіації можливості її реалізації з урахуванням обсягів державного фінансування Сектору безпеки и оборони України на середньо- і довгостроковій перспективі.

\section{Виклад основного матеріалу}

Оскільки, як відомо, підтримка та розвиток (переозброєння) авіаційної компоненти є найбільш витратною складовою збройних сил для будь-якої країни, це обумовлює необхідність проведення ретельних досліджень щодо обгрунтування як кількісно-якісних показників програм розвитку систем OBТ тактичної авіації, так і прогнозних показників фінансових витрат на їх забезпечення.

Результати попередніх досліджень щодо формування формалізованих критеріїв раціональності програм розвитку системи ОВТ тактичної авіації, як системоутворюючих складових розробленого комплексного системного науково-методичного апарату, дозволяють синтезувати програми розвитку системи ОВТ тактичної авіації відповідно до обраної стратегії ії розвитку [25-28]. У якості альтернативних стратегій розвитку системи ОВТ тактичної авіації пропонується розглядати наступні їх варіанти:

- стратегія сталого розвитку, яка передбачає, що рівень спроможностей тактичної авіації у виконанні визначених завдань відповідно до сценарію іiі застосування нарощуватиметься поступово та досягне необхідного рівня наприкінці періоду планування із оптимальним розподілом фінансового ресурсу на всій глибині планування (стратегія № 1);

- стратегія швидкої (невідкладної) ліквідації нестачі спроможності за мінімально можливий час (стратегія № 2), яка може мати місце при несприятливому прогнозі зміни оперативного середовища, котрі обумовлюватимуть необхідність термінового нарощування спроможностей тактичної авіації для іiі здатності до виконання визначених бойових (оперативних) завдань на належному необхідному рівні у відповідних сценаріях застосування із залученням усіх можливих джерел фінансування для здійснення закупівлі тактичних літаків (ймовірне залучення кредитних ресурсів міжнародних партнерів, альтернативні програми лізингу, або оренди бойових літаків, тощо);

- стратегія постійної ліквідації нестачі спроможності вздовж всього періоду планування, коли на кінець періоду планування за результатами прогнозу зміни оперативного середовища, прогнозу обсягів фінансування програми переозброєння та тенденцій розвитку світового ринку озброєнь може очікуватися недосягнення необхідного рівня спроможностей у виконанні визначених завдань, причиною чого може бути або невідповідне фінансування програми переозброєння, або неможливість здійснювати закупівлю літаків тактичної авіації навіть при наявності достатнього фінансового ресурсу (стратегія № 3).

Для кожного варіанту стратегії розвитку системи ОВТ тактичної авіації в публікаціях [26-28] розроблено формалізовані критерії раціональності програми розвитку, важливою складовою яких $є$ фінансові показники витрат на переозброєння, а також запропоновано методичні підходи до розв'язування задач синтезу раціональних програм розвитку системи озброєння тактичної авіації на основі постановки та розв'язування відповідних математичних задач оптимізації.

Для стратегії сталого розвитку (стратегія № 1) відповідно до розробленого формалізованого критерію раціональності реалізація синтезованої програми розвитку системи ОВТ гарантує набуття необхідних спроможностей в задані терміни при мінімальних витратах фінансового ресурсу на всій глибині планування. У формалізованому вигляді такий критерій описується наступним виразом [26-27]:

$$
\left\{\begin{array}{l}
\int_{t_{0}}^{T_{\text {зад }}} \sum_{j=1}^{n} K_{\text {БПij }} \sum_{r=1}^{R} \delta_{i j r} \dot{X}_{r j}(t) d t \geq \Delta P_{i}\left(T_{\text {зад }}\right), \forall i=\overline{1, m} ; \\
S=\int_{t_{0}}^{T_{\text {зад }}} \sum_{j=1}^{n}\left(C_{1 j}+C_{1 j}^{\text {eксnл }}(t)\right) \sum_{r=1}^{R} \dot{X}_{j r}(t) d t \rightarrow \mathrm{min} ; \\
T_{\text {гот } i} \leq T_{\text {зад }}, \forall i=\overline{1, m},
\end{array}\right.
$$

де $n$-кількість типів літальних апаратів, що входить до оновленого парку літаків бойового складу тактичної авіації;

$m$-кількість бойових завдань із сукупності завдань, що визначені до виконання авіаційним угрупованням по всіх можливих сценаріях застосування тактичної авіації;

$\delta_{i j r}$ - символ, який характеризує можливість залучення засобів $j$-го типу до виконання $i$-го бойового завдання та інших бойових завдань з сукупності $m$ завдань водночас у відповідності до визначеної структури бойового потенціалу авіаційного угруповання $\left(\delta_{i j r}=1\right.$ - при можливості одним і тим же засобом $j$-го типу виконувати бойове завдання $i$-го типу водночас з завданням $r$-го типу, та $\delta_{i j r}=1-$ при неможливості цього);

$R$ - загальна кількість можливих варіантів розподілу наявної кількості бойових літаків по бойових завданнях, виставлене постановником задачі оптимізації в залежності від властивостей альтернативних типів багатофункціональних винищувачів, максимальне значення якої може дорівнювати числу 
розміщень значень символу $\delta_{i j r}(0$ або 1$)$ по кількості бойових завдань $m$, включаючи варіанти залучення одних й тих же засобів до виконання всіх завдань, а також варіанту їх незалучення до виконання жодного з завдань $R_{\max }=A_{m}^{2}+2$;

$K_{\text {бпij }}$ - значення коефіцієнту бойового потенціалу у вирішенні $i$-ого завдання зразком $j$-ого типу; $\Delta P_{i}\left(T_{\text {зад }}\right)$ - нестача (дефіцит) спроможності тактичної авіації у виконанні $i$-ого бойового завдання наприкінці глибини планування розвитку спроможностей $T_{\text {зад }}$;

$\left[t_{0}, T_{\text {зад }}\right]$ - інтервал часу, на якому здійснюється синтез програми розвитку системи озброєння авіації ПС ЗС України;

$\dot{X}_{j r}(t)$ - похідна за часом функції кількості літаків $j$-ого типу, які треба поставити у війська, та які повинні забезпечити набуття спроможності тактичної авіації у виконанні $r$-го бойового (оперативного) завдання (темп оновлення парку за рахунок літаків даного типу);

$C_{1 j}$ - вартість закупівлі одного серійного літака $j$-ого типу;

$C_{1 j}^{\text {експл }}(t)$ - функція розподілу за часом експлуатаційних витрат на один літак $j$-го типу;

$S$ - обсяг фінансового ресурсу, необхідного для набуття необхідних спроможностей тактичною авіацією за рахунок закупівлі нових літаків.

Знайдене рішення математичної задачі оптимізації (1) буде відповідати такому варіанту програми, при якому обсяг потрібних для оснащення тактичної авіації ресурсів буде мінімальним. Треба зауважити, що будь-який інший варіант задоволення потреб у рівні необхідних спроможностей тактичної авіації (що також задовольняє обмеженням задачі (1)), буде апріорі вимагати витрат більших обсягів ресурсів, чим знайдене рішення. При цьому, далеко не завжди знайдений мінімальний обсяг потрібних на закупівлю та постачання нової техніки у війська ресурсів буде відповідати економічним спроможностям держави. Відтоді, остаточне прийняття рішення про прийняття синтезованої програми або ії̈ відхилення буде вимагати або пошуку додаткових ресурсів на іï реалізацію, або зменшення рівня виконання покладених на тактичну авіацію завдань, або взагалі перегляду сценарію іiї застосування в складі збройних угруповань, в залежності від ступеню невідповідності необхідних обсягів ресурсного забезпечення та наявних ресурсів. Хоча в явному вигляді в формалізованому критерії для цієї стратегії відсутні показники максимального обсягу фінансових видатків, що можуть виділятися державою на переозброєння тактичної авіації, з оглядом на вищенаведене, для інтерпретації результатів розв'язування математичної задачі оптимізації виду (1) та прийняття рішення про придатність або не придатність синтезованого варіанту програми розвитку системи ОВТ такі дані повинні бути в наявності.

Стратегія швидкої (невідкладної) ліквідації нестачі спроможностей за мінімально можливий час (стратегія № 2) передбачає реалізацію програми набуття необхідних спроможностей, синтезованої відповідно до наступного формалізованого критерію іiі раціональності [26-28]:

$$
\begin{aligned}
& \iint_{t_{0}}^{t_{i}} \sum_{j=1}^{n} K_{\text {бnij }} \sum_{r=1}^{R} \delta_{i j r} \dot{X}_{r j}(t) d t \geq \Delta P_{i}(t), \forall i=\overline{1, m} ; \\
& S=\int_{t_{0}}^{\max } \sum_{j=1}^{i} C_{1 j} \sum_{r=1}^{R} \dot{X}_{r j}(t) d t \leq S_{3 а д}\left(\begin{array}{c}
\max _{i} t_{i} \\
i
\end{array}\right) ; \\
& T_{\text {гоm }}(t)=\max _{i}\left(t_{i}\right) \rightarrow \min , \forall i=\overline{1, m} \text {, }
\end{aligned}
$$

де $t_{0}$ - початок терміну планування;

$t_{i}$ - час набуття необхідного рівня спроможностей тактичною авіацією у виконанні $i$-ого бойового завдання $з m$ на неї покладених;

$T_{\text {гот }}(t)$ - час набуття необхідного рівня спроможності тактичною авіацією у виконанні всіх $m$ на неї покладених бойових завдань;

$\max _{i}\left(t_{i}\right)$ - найбільший час, 3 усіх потрібних часів набуття спроможності по кожному $3 ~ m$ визначених бойових завдань, покладених на тактичну авіацію;

$$
S_{\text {зад}}\left(\underset{i}{\max } t_{i}\right) \text { - обсяг фінансового ресурсу, що }
$$

може бути виділений (або отриманий) для нарощення спроможності до необхідного рівня, що описуються виразом

$$
S_{\text {зад }}\left(\begin{array}{c}
\max t_{i} \\
i
\end{array}\right)=\int_{t_{0}}^{\max t_{i}} \dot{S}_{3 a \partial}(t) d t,
$$

де $\dot{S}_{\text {зад }}(t)$ - розподіл за часом на плановому періоді всього об'єму ресурсів, який за прогнозом економічного розвитку держави, може бути виділеним на оновлення парку тактичних літаків без створення умов щодо надмірного напруження для державного бюджету.

3 аналізу складових формалізованого критерію раціональності програми розвитку системи ОВТ тактичної авіації (2), витікає, що без інформації про максимально можливі обсяги фінансових ресурсів, 
що може бути виділеними на окремих відрізках часу на всій глибині планування, постановка математичної задачі оптимізації такої програми взагалі не можлива, окрім випадку, коли обмеження на ресурси можуть бути знятими (наприклад, у випадку вимушеної мобілізації при швидкоплинному загостренні воєнної загрози та вирішення проблеми переозброєння за рахунок боргових зобов'язань).

Відповідно до критерію раціональності програми розвитку системи ОВТ виду (2) синтезована програма буде вважатися раціональною за умови найскорішого набуття необхідних спроможностей тактичною авіацією по всіх без виключення покладених на неї бойових (оперативних) завдань. Такий варіант набуття необхідних спроможностей є найбільш витратним на початковому етапі планування (реалізації) такої програми. До речі, з оглядом на об'єктивно несприятливу ситуацію, яка склалася та обумовлена спливанням термінів експлуатації майже всього парку бойової авіаційної техніки тактичної авіації ПС ЗС України [29], виникає необхідність термінової закупівлі значної кількості тактичних літаків, що неминуче потягне за собою значні фінансові витрати. Це $є$ передумовою проведення на етапі планування переозброєння тактичної авіації за Стратегією № 2 ретельного оцінювання обсягу можливого фінансування програми на всій глибині планування та відповідності йому необхідних обсягів фінансування набуття визначених спроможностей тактичною авіацією за рахунок оновлення парку бойових літаків. Є підстави вважати [29], що видатків Державного бюджету України на Міністерство оборони України, а саме на Державну цільову про- граму 2101150 “Розвиток, закупівля, модернізація та ремонт озброєння, військової техніки, засобів та обладнання" в частині фінансування тактичної авіації може виявитися недостатньо для термінового набуття необхідних спроможностей тактичною авіацією ПС ЗС України [30-32].

Тому, як і для варіанту розвитку системи ОВТ за стратегією № 1, прогнозування обсягів наявного фінансового ресурсу, виділених на забезпечення набуття необхідних спроможностей тактичною авіацією за стратегією № 2, уявляється виключно важливим.

При синтезі програми розвитку системи ОВТ тактичної авіації за стратегією № 3 постає аналогічне питання, оскільки такий варіант нарощування спроможностей стає доцільним за умови неможливості реалізації перших двох стратегій, внаслідок недостатності фінансування набуття всіх необхідних спроможностей (у представленій публікації не розглядається обмеженість нарощування спроможностей тактичної авіації через несприятливі тенденції розвитку світового ринку озброєнь). У такому разі мова може йти про нарощування найбільшої можливої кількості спроможностей, або максимального нарощування пріоритетних спроможностей тактичної авіації у відповідності до визначених сценаріїв застосування. Формалізований критерій раціональності програми розвитку системи ОВТ за стратегією № 3, що, зокрема, відображає важливість оцінювання фінансових показників ресурсного забезпечення програми розвитку системи ОВТ тактичної авіації, має наступний вигляд [26-28]:

$$
\left\{\begin{array}{l}
\int_{t_{0}}^{t} \sum_{j=1}^{n} K_{\text {БПij }} \sum_{r=1}^{R} \delta_{i j r} \dot{X}_{j r}(t) d t \rightarrow \max , \forall i=1, \ldots, m^{*} \forall t \in\left[t_{0}, T_{3 а д}\right] \\
\int_{t_{0}}^{t} \sum_{j=1}^{n} C_{1 j} \sum_{r=1}^{R} \dot{X}_{r j}(t) d t \leq S_{\text {зад }}(t), \forall j=\overline{1, n}, \forall t \in\left[t_{0}, T_{3 а д ~}\right] \\
T_{\text {гот } i}<T_{\text {зад }}, \forall i=1, \ldots, m^{*},
\end{array}\right.
$$

де $m^{*}$ - кількість пріоритетних бойових (оперативних) завдань, нарощування спроможностей у виконанні яких є надважливим та першочерговим.

Обмеження на фінансові ресурси, що можуть бути виділеними державою за відповідним цільовим призначенням на всій глибині планування, $є$ невід'ємною складовою формалізованого критерію (3), без якої математична задача оптимізації програми розвитку ОВТ тактичної авіації взагалі неможлива.

Таким чином, в усіх розглянутих можливих варіантах обрання стратегії розвитку системи ОВТ тактичної авіації та відповідних формалізованих критеріях раціональності програм розвитку, що ма- ють бути застосованими в практиці оборонного планування, визначення наявного ресурсного забезпечення розвитку системи ОВТ тактичної авіації є невід'ємною складовою процесу синтезу раціональної програми.

Відповідно до чинного законодавства [33-35] та певної синхронізації фінансового планування витрат Державного бюджету України на короткостроковій перспективі із плануванням витрат Міністерства оборони України, що відповідає трирічному циклу планування, актуальним залишається недосконалість методичних підходів до прогнозування обсягів державних витрат на сектор безпеки та оборо- 
ни, які можуть бути відділеними на середньо- та довгостроковій перспективі, зокрема, на розвиток системи ОВТ тактичної авіації. В той же час, статтею 35 Закону України про Національну безпеку України передбачено фінансування складових сектору безпеки і оборони за рахунок і в межах коштів, визначених у Законі України про Державний бюджет України на відповідний рік на рівні не менше $5 \%$ запланованого обсягу внутрішнього валового продукту (ВВП), з яких не менше 3\% - на фінансування сил оборони. В свою чергу, державне фінансування програми розвитку системи ОВТ тактичної авіації шляхом закупівлі літаків тактичної авіації можливе в рамках реалізації Державної цільової програми 2101150 "Розвиток, закупівля, модерніза- ція та ремонт озброєння, військової техніки, засобів та обладнання". За результатами проведеного аналізу видатків Міністерства оборони (МО) України за останні 9 років (2014-2022 р.p.) встановлено, що видатки за програмою 2101150 орієнтовно складають у загальному обсязі цих видатків в середньому близько $20 \%$ [36-45] (табл. 1).

Це дає підгрунтя для проведення оцінювання можливих обсягів фінансування за рахунок Державного бюджету України Міністерства оборони України, в тому числі заходів щодо розвитку систем ОВТ, взагалі, та системи ОВТ тактичної авіації, зокрема, за умови збереження за часом аналогічних питомих часток обсягів державного фінансування сектору безпеки і оборони.

Таблиця 1

Видатки МО України за Державною цільовою програмою 2101150 “Розвиток, закупівля, модернізація та ремонт озброєння, військової техніки, засобів та обладнання"

\begin{tabular}{|c|c|c|c|}
\hline Рік & $\begin{array}{c}\text { Бюджет МО України, } \\
\text { грн. }\end{array}$ & $\begin{array}{c}\text { Витрати за програмою 2101150, } \\
\text { грн. }\end{array}$ & $\begin{array}{c}\text { Відсоток від бюджету } \\
\text { МО України }\end{array}$ \\
\hline 2014 & 27346300,00 & 5349901,08 & 14,63 \\
\hline 2015 & 49084000,00 & 5679000,00 & 11,57 \\
\hline 2016 & 55600000,00 & 11500000,00 & 20,68 \\
\hline 2017 & 69175200,00 & 14615100,00 & 21,13 \\
\hline 2018 & 86014500,00 & 16357006,30 & 19,02 \\
\hline 2019 & 101400000,00 & 17000000,00 & 19,77 \\
\hline 2020 & 118012998,10 & 22703508,90 & 19,35 \\
\hline 2021 & 117504702,00 & 22742438,50 & 21,7 \\
\hline 2022 & 130988435,00 & 28438101,80 & \\
\hline
\end{tabular}

Джерело: [36-45].

Для можливості оцінювання прогнозних показників видатків Міністерства оборони України за програмою 2101150, перш за все, необхідно оцінити прогнозні показники ВВП України на довгострокову перспективу. Відповідно до аналітичної інформації Світового банку, Міністерства фінансів України, Українського інституту майбутнього прогноз щорічного приросту реального ВВП держави орієнтовно на довгостроковій перспективі може скласти на рівні $3 \%[31 ; 46 ; 47]$.

Таким чином, маючи прогнозні показники ВВП на довгостроковій перспективі можливо провести оцінювання динаміки можливого обсягу фінансування видатків Міністерства оборони України, зокрема за Державною цільовою програмою 2101150. Для приведення фінансових розрахунків до єдиного виміру вбачається доцільним розглядати усі фінансові показники із фіксованим фінансовим роком розрахунку, а саме 2014 фінансового року. Результати такого оцінювання, які базуються на використанні доступної офіційної інформації [46-49], наведені в табл. 2.

Таблиця 2

Результати прогнозу динаміки ВВП України та видатків Державного бюджету до 2035 року (constant 2014 US \$)

\begin{tabular}{|c|c|c|c|}
\hline Рік & $\begin{array}{c}\text { Прогноз ВВП } \\
\text { (bil.constant 2014 US \$) }\end{array}$ & $\begin{array}{c}\text { Прогноз видатків } \\
\text { Державного бюджету } \\
\text { України на МО України } \\
\text { (bil.constant 2014 US \$) }\end{array}$ & $\begin{array}{c}\text { Прогноз видатків МО } \\
\text { України за програмою } \\
2101150 \\
\text { (bil.constant 2014 US \$) }\end{array}$ \\
\hline 1 & 2 & 3 & 4 \\
\hline 2021 & 171,05 & 5,13 & 1,06 \\
\hline 2022 & 176,18 & 5,29 & 1,09 \\
\hline 2023 & 181,47 & 5,44 & 1,12 \\
\hline 2024 & 186,91 & 5,61 & 1,16 \\
\hline 2025 & 192,52 & 5,78 & 1,19 \\
\hline 2026 & 198,30 & 5,95 & - \\
\hline
\end{tabular}


Закінчення табл. 2

\begin{tabular}{|c|c|c|c|}
\hline 1 & 2 & 3 & 4 \\
\hline 2027 & 204,25 & 6,13 & 1,23 \\
\hline 2028 & 210,37 & 6,31 & 1,26 \\
\hline 2029 & 216,68 & 6,50 & 1,30 \\
\hline 2030 & 223,18 & 6,70 & 1,34 \\
\hline 2031 & 229,88 & 6,90 & 1,38 \\
\hline 2032 & 236,78 & 7,10 & 1,42 \\
\hline 2033 & 243,88 & 7,32 & 1,46 \\
\hline 2034 & 251,20 & 7,54 & 1,51 \\
\hline 2035 & 258,73 & 7,76 & 1,55 \\
\hline
\end{tabular}

Джерело: [46-49].

Світова практика фінансування програм розвитку систем озброєння та військової техніки свідчить, що витрати на розвиток парків бойової авіаційної техніки орієнтовно складають від 17,9\% до 27\% від

загального обсягу фінансів, спрямованих міністерствами оборони провідних країн світу на розвиток ОВТ збройних сил [50-52] (табл. 3).

Видатки провідних країн світу на закупівлю ОВТ в інтересах Військово-Повітряних Сил (constant 2014 US \$)

\begin{tabular}{|l|c|c|c|c|c|}
\hline & $\begin{array}{c}\text { Сумарні } \\
\text { витрати } \\
\text { на оборону, } \\
\text { (bil.constant } \\
2014 \text { US \$) }\end{array}$ & $\begin{array}{c}\text { Закупівлі } \\
\text { ОВT, } \\
\text { в витрат MO }\end{array}$ & $\begin{array}{c}\text { Закупівлі } \\
\text { OBT, } \\
\text { (bil.constant } \\
2014 \text { US \$) }\end{array}$ & $\begin{array}{c}\text { Доля ВВС в } \\
\text { бюджеті } \\
\text { MO, \% }\end{array}$ & $\begin{array}{c}\text { Закупівля ОВТ } \\
\text { ВВС, } \\
\text { (bil.constant } \\
2014 \text { US \$) }\end{array}$ \\
\hline США & 682,46 & 20,00 & 136,49 & 27 & 36,85 \\
\hline Великобританія & 51,93 & 21,90 & 11,37 & 22,3 & 2,54 \\
\hline Німеччина & 46,32 & 16,80 & 7,78 & 17,9 & 1,39 \\
\hline Франція & 54,19 & 23,70 & 12,84 & 22,1 & 2,84 \\
\hline РФ & 54,12 & 55,00 & 29,77 & 21 & 6,25 \\
\hline Україна & 4,6 & 21,7 & 0,8 & 21,5 & 0,21 \\
\hline
\end{tabular}

Джерело: [50-52].

За результатами аналізу даних, наведених у табл. 3 встановлено, що розподіл Державного бюджету України, зокрема щодо фінансування Державної цільової програми 2101150 “Розвиток, закупівля, модернізація та ремонт озброєння, військової техніки, засобів та обладнання" відповідає світовим тенденціям щодо фінансування аналогічних програм.

Але, по-перше, абсолюті показники фінансування видатків на оборону України є майже не порівняними із відповідними видатками провідних країн світу, та складають в середньому лише близько $6 \%$ від них.

По-друге, що стосується обсягів фінансування закупівлі ОВТ в інтересах ПС ЗС України, які б мали скласти орієнтовно 21,5\% бюджету програми 2101150 і що корелює із аналогічними витратами провідних країн світу, то, як свідчить розподіл видатків за програмою 2101150 за останні роки, такого рівня фінансування не відбувалось.

Це призвело до ситуації необхідності термінового пошуку шляхів переозброєння бойової авіацій- ної техніки, що обумовлено неминучим вичерпанням показників призначеного технічного ресурсу одночасно для значної кількості літаків тактичної авіації у найближчій перспективі.

Однак, якщо припустити, що на глибині планування розвитку системи ОВТ тактичної авіації будуть збережені обсяги фінансування Збройних Сил України і тенденції наявного розподілу коштів за Державними цільовими оборонними програмами, та спираючись на обсяги відповідного фінансування авіаційної компоненти збройних сил провідних країн світу, можна очікувати, що максимальний обсяг цільових видатків Державного бюджету України, які можуть бути використані для переозброєння тактичної авіації ПС ЗС України, складе орієнтовно 3,88 млрд. дол. (constant 2014 US \$) з їх розподілом по роках планового періоду, як наведено в табл. 4.

Наведене вище дозволяє запропонувати методичний підхід до оцінювання можливості реалізації за ресурсним забезпеченням програми розвитку системи ОВТ тактичної авіації на етапі їі синтезу. 
Результати прогнозу видатків Державного бюджету України до 2035 року, що можуть бути спрямовані на переозброєння тактичної авіації (constant 2014 US \$)

\begin{tabular}{|c|c|c|c|}
\hline Рік & $\begin{array}{c}\text { Прогноз видатків МО України } \\
\text { за програмою } 2101150 \\
\text { (bil.constant 2014 US \$) }\end{array}$ & $\begin{array}{c}\text { Прогноз видатків на } \\
\text { закупівлю OBТ ПС 3С } \\
\text { України (bil.constant 2014 } \\
\text { US \$) } \\
\end{array}$ & $\begin{array}{c}\text { Прогноз видатків за } \\
\text { ймовірними інтервалами } \\
\text { програми переозброєння } \\
\text { (bil.constant 2014 US \$) } \\
\end{array}$ \\
\hline 2022 & 1,06 & 0,23 & \multirow{2}{*}{0,95} \\
\hline 2023 & 1,09 & 0,23 & \\
\hline 2024 & 1,12 & 0,24 & \multirow{2}{*}{0,95} \\
\hline 2025 & 1,16 & 0,25 & \\
\hline 2026 & 1,19 & 0,26 & \multirow{5}{*}{1,36} \\
\hline 2027 & 1,23 & 0,26 & \\
\hline 2028 & 1,26 & 0,27 & \\
\hline 2029 & 1,30 & 0,28 & \\
\hline 2030 & 1,34 & 0,29 & \\
\hline 2031 & 1,38 & 0,30 & \multirow{5}{*}{1,57} \\
\hline 2032 & 1,42 & 0,31 & \\
\hline 2033 & 1,46 & 0,31 & \\
\hline 2034 & 1,51 & 0,32 & \\
\hline 2035 & 1,55 & 0,33 & \\
\hline Загалом: & 18,06 & 3,88 & 3,88 \\
\hline
\end{tabular}

Джерело: розроблено автором.

У випадку, якщо при синтезі раціональної програми розвитку системи ОВТ тактичної авіації обирається стратегія № 1 та застосовується формалізований критерій раціональності (1) порядок оціню-

вання можливості реалізації синтезованої програми за обмеженнями фінансових ресурсів має вигляд, як показано схематично на рис. 1.

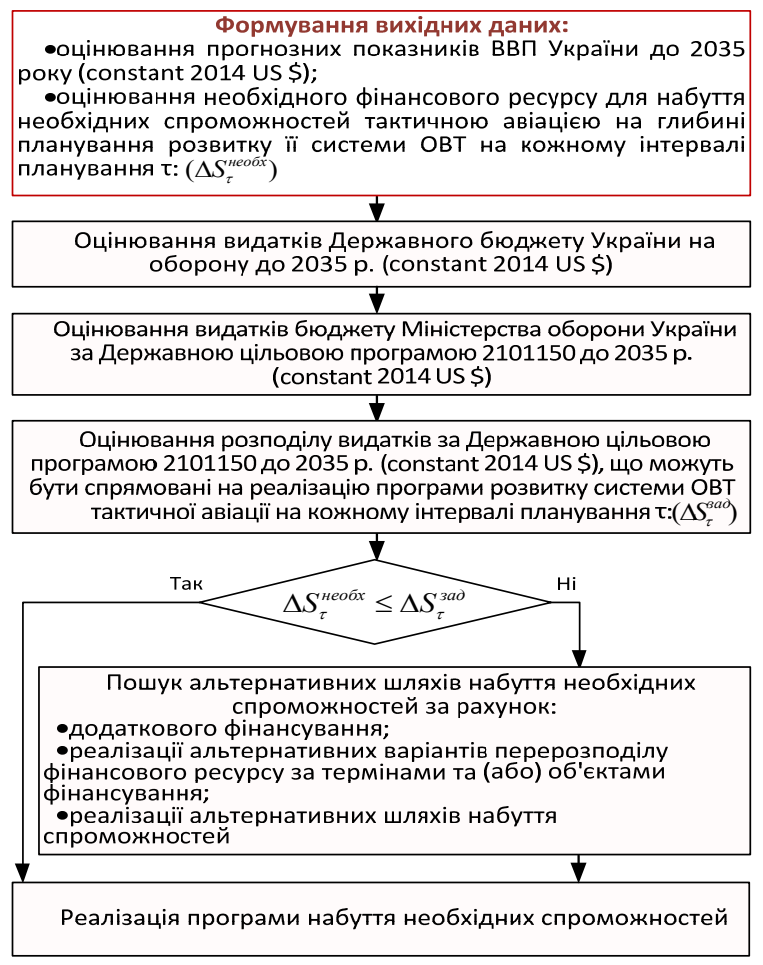

Рис. 1. Методичний підхід до оцінювання можливості реалізації синтезованого за критерієм (1) раціонального варіанту програми розвитку системи ОВТ тактичної авіації на етапі ії синтезу за обмежених фінансових спроможностей держави Джерело: розроблено автором. 
Початковими даними в розробленій методиці оцінювання фінансової реалізуємості програми розвитку системи озброєння та військової техніки тактичної авіації на етапі iї синтезу, що пропонується є:

- прогнозні показники реального ВВП України до 2035 року, за фіксованим курсом US \$ станом на 2014 рік, наприклад за інформацією Світового банку [46-47];

- оцінки необхідного фінансування заходів щодо переозброєння парку бойової авіаційної техніки, що отримані за результатами синтезу раціональної програми розвитку системи ОВТ тактичної авіації на всій глибині планування за методиками, що детально викладені в статтях [53-55].

Для оцінювання витрат на переоснащення парку бойових літаків тактичної авіації, що повинні бути задоволені відповідним фінансуванням, необхідно виокремити із загальної вартості програми розвитку системи ОВТ тактичної авіації фінансові витрати, необхідні для закупівлі нових тактичних літаків, що реалізовуватиметься в межах Державної цільової програми 2101150, оскільки за критерієм (1) при визначенні вартості програми використовується загальна вартість життєвого циклу літака на всій глибині планування розвитку.

На першому етапі оцінюються прогнозні видатки Державного бюджету України на сили оборони, виходячи з вимог чинного законодавства щодо унормування рівня фінансування МО України.

Це дозволить на наступному кроці оцінити обсяги фінансування Державної цільової програми 2101150 , якщо припустити, що на середньо- та довгостроковій перспективі тенденції формування бюджету МО України та обсяги його фінансування будуть аналогічні тим, що спостерігаються останнім часом.

Наявність прогнозних оцінок необхідного фінансування заходів програми розвитку системи OBT, з обсягами фінансового ресурсу, що може забезпечити Державний бюджет України, дає можливість порівняти їх відповідність на кожному із визначених інтервалів часу на всій глибині програми. За результатами такого оцінювання на етапі синтезу програми розвитку системи ОВТ тактичної авіації для ОПР, у разі виявлення неадекватності необхідного фінансування програми можливому, є перспективи своєчасного внесення коректив до синтезованої раціональної програми до початку іiі реалізації, що значною мірою буде сприяти зниженню ризиків не набуття (розвитку) тактичною авіацією необхідних спроможностей у виконанні завдань відповідно до сценаріїв застосування ПС ЗС України.

У випадку виявлення недостатності запланованих ресурсів для набуття тактичною авіацією необхідних спроможностей можуть розглядатися варіанти додаткового фінансування програми за рахунок бюджету держави, міжнародної допомоги, інших не заборонених джерел інформації. У якості міжнародної допомоги може розглядатися міжнародна технічна допомога - поставка іншими державами Збройним Силам України озброєння та військової техніки, матеріально-технічного забезпечення, технічної документації для підтримання та розвитку наявних спроможностей. Такий варіант, зокрема, може розглядатися для забезпечення розвитку критичних спроможностей.

У випадку, якщо при синтезі програми розвитку системи ОВТ тактичної авіації обирається стратегія № 2 або стратегія № 3, з використанням формалізованого критерію (2) або (3), застосовується лише тільки перші чотири етапи методики, наведеної на рис. 1, для формування системи початкових даних постановки відповідних математичних задач оптимізації. Розв'язування таких поставлених математичних задач оптимізації програми здійснюється за методиками, викладеними в статтях [26-28], де дотримання балансу між потрібним обсягом фінансування та наявними виділеними ресурсами передбачено в самому алгоритмі синтезу раціональної програми.

Також у випадку неадекватності наявного (або такого, що планується бути в наявності) фінансового ресурсу потрібним обсягам фінансування набуття необхідних спроможностей та обмежених можливостей щодо додаткового фінансування та перерозподілу коштів Державного бюджету України можливий розгляд альтернативних шляхів набуття необхідних спроможностей, або пошук асиметричних дій 3С України, але ці питання виходять за межі досліджень, що розглянуті в даній роботі.

\section{Висновки}

Розроблено методичний підхід до оцінювання можливості реалізації програми розвитку системи ОВТ тактичної авіації на етапі іiї синтезу з урахуванням фінансових спроможностей держави на середньо- і довгостроковій перспективі, який в залежності від обрання виду стратегії розвитку, дозволяє здійснити підтримку управлінських рішень про придатність або не придатність до реалізації синтезованого варіанту програми та визначитись 3 наступними напрямками пошуку задовільних рішень щодо шляхів усунення дефіциту спроможностей тактичної авіації.

Своєчасне оцінювання можливості реалізації за виділенням обмеженого обсягу фінансових ресурсів варіанту раціональної програми розвитку системи озброєння та військової техніки тактичної авіації, а саме - на етапі синтезу програм набуття необхідних спроможностей, дозволить уникнути прийняття термінових рішень щодо корегування вже прийнятих до реалізації програм розвитку спроможностей, та уникнути стратегічних помилок, наслідками яких можуть 
стати значні втрати у майбутньому (критичної втрати часу, перевитрати фінансових ресурсів, неефективне використання економічного потенціалу держави, тощо). В цілому це забезпечить підтримку процесу прийняття рішень на середньо- та довгостроковій перспективі, дозволить підвищити якість оборонного планування розвитку ПС ЗС України, сприятиме своєчасному формуванню необхідних оперативних (бойових, спеціальних) спроможностей, зокрема, тактичної авіації, які забезпечуватимуть гарантування за- хисту повітряного простору держави.

Запропонований методичний підхід є складовою системного науково-методичного апарату синтезу раціональної програми розвитку системи озброєння та військової техніки тактичної авіації, але може бути застосованим на практиці для відокремленого використання при вирішенні задач, що потребують отримання прогнозів наявного обсягу фінансових ресурсів на періоді планування розвитку спроможностей.

\section{Список літератури}

1. Рекомендації з оборонного планування на основі спроможностей в Міністерстві оборони України та Збройних Силах України : Рекомендації затверджено Міністром оборони України від 12 черв. 2017 р. Київ : MOУ, 2017. 29 с. URL: https://www.mil.gov.ua/content/other/Recommendationson_CBP_120617.pdf (дата звернення: 01.11.21).

2. Методичні рекомендації з організації та проведення оборонного огляду. Затверджені МОУ від 10 черв. 2019 р. № 9262/3. URL: https://www.mil.gov.ua/diyalnist/reformi-ta-planuvannya-u-sferi-oboroni/plani-ukraina-2020/metodichnirekomendaczii-z-organizaczii-ta-provedennya-oboronnogo-oglyadu-yaki-zatverdzheno-ministrom-oboroni-ukraini-7-chervnya2019-roku-(zatverdzheni-mou-vid-10-chervnya-2019-\%E2\%84\%96-9262/z).html (дата звернення: 01.11.21).

3. Про затвердження Порядку проведення оборонного огляду Міністерством оборони : Постанова Кабінету Міністрів України від 31 жовт. 2018 p. № 941. URL: https://www.mil.gov.ua/diyalnist/reformi-ta-planuvannya-u-sferioboroni/postanova-kmu-pro-zatverdzhennya-poryadku-provedennya-oboronnogo-oglyadu-ministerstvom-oboroni.html (дата звернення: 01.11.21).

4. Про затвердження Порядку організації та здійснення оборонного планування в Міністерстві оборони України, Збройних Силах України та інших складових сил оборони : Наказ Міністерства оборони України від 20 січ. 2020 р. № 484. URL: https://zakon.rada.gov.ua/laws/show/z0196-21\#Text (дата звернення: 01.11.21).

5. Руснак I. С., Загорка О. М. Розвиток методологічних положень обгрунтування заходів організаційного будівництва (реформування) Повітряних Сил ЗС України. Наука і оборона. 2010. №1. С. 6-12.

6. Чепков І. Б., Луханін М. І., Борохвостов І. В. Основні аспекти методології формування та супроводження реалізації середньострокових програм озброєння в умовах особливого періоду. Озброєння та військова техніка. 2016. № 4(2). С. 3-8.

7. Демидов Б. А. Луханин М. И., Величко А. Ф., Науменко М. В. Системная методология планирования развития, предпроектных исследований и внешнего проектирования вооружения и военной техники : монография / под ред. Б. А. Демидова. Київ : “Стилос”, 2011. 464 с.

8. Оборонна реформа: системний підхід до оборонного менеджменту : монографія / Павліковський А. та ін., за заг. ред. А. Сиротенка. Київ : НУОУ, 2020. 274 с.

9. Оборонний огляд: український вимір 2014 -2018 : монографія / Саганюк Ф. та ін., за заг. ред. І. Руснака. Київ : МО та ГШ ЗС України, НУОУ, 2019. 196 с.

10 Борохвостов І. В., Білокур М. О. Визначення критеріїв та методів оцінювання шляхів забезпечення військових формувань озброєнням та військовою технікою. Озброєння та військова техніка. 2018. № 3(19). С. 3-8.

11. Семон Б. Й., Леонтьєв О. Б. Сучасний метод бойових потенціалів в прикладних задачах планування розвитку та застосування тактичної авіації: монографія. Київ : НАОУ, 2009. 336 с.

12. Котов О. Б., Романченко І. С. Обгрунтування вибору критеріїв раціональності кількісно-якісного складу повітряної компоненти міжвидового збройного угруповання. Збірник наукових пращь Харківського університету Повітряних Сил. 2012. № 3(9). С. 14-17.

13. Дроздов С. С., Леонтьєв О. Б. Методика постановки та розв'язування зворотної задачі оптимізації бойового (кількісно-якісного) складу тактичної авіації і зенітних ракетних військ перспективних Повітряних Сил. Наука $i$ техніка Повітряних Сил Збройних Сил України. 2017. № 2(27). С. 7-14.

14. Дроздов С. С., Леонтьєв О. Б., Науменко М. В. Методичний підхід до розв'язування математичної задачі синтезу раціональної програми розвитку системи озброєння тактичної авіації на основі критерію мінімізації фінансових витрат за умови досягнення необхідних бойових спроможностей. Наука і техніка Повітряних Сил Збройних Сил Украӥни. 2020. № 4(41). C. 54-63. URL: https://doi.org/10.30748/nitps.2020.41.06.

15. Бойко Р. В., Семененко О. М., Кремешний О. І., Чернишова I. М. Формування порядку воєнно-економічного оцінювання результатів виконання заходів та програм розвитку Збройних Сил України. Систели озброєння $і$ військова техніка. 2011. № 3(27). С. 98-101.

16. Семененко О. М. Водчиць О. Г., Семененко Л. М., Бойко Р. В., Башинський Д. В., Зубрицька Г. Г. Метод оцінювання ефективності виконання програм (планів) розвитку збройних сил України з урахуванням повноти та своєчасності їх фінансування. Збірник наукових праџъь Харківського національного університету Повітряних Сил. 2017. № 2(51). C. 51-58.

17. Кремешний О. І., Бойко Р. В., Семененко О. М., Чернишова І. М. Методичний підхід щодо підвищення ефективності виконання заходів програм розвитку Збройних Сил України шляхом раціонального розподілу фінансових ресур- 
сів на них. Збірник наукових пращъь Харківського начіонального університету Повітряних Сил. 2012. № 2(31). С. 19-23.

18. Семененко О. М. Дідіченко В. П., Савостьянов А. Ф., Слюсаренко М. О. Щодо оцінювання результатів виконання заходів програм розвитку Збройних Сил України за плановий період. Збірник наукових пращь Центрального науково-дослідного інституту Збройних Сил Украӥни. 2010. № 4 (54). C. 33-45. https://doi.org/10.30748/zhups.2017.51.10.

19.Семененко О. М. Методичний апарат оцінювання результатів виконання заходів Державних програм реформування та розвитку Збройних Сил України. Збірник наукових праць Центрального науково-дослідного інституту Збройних Сил України. 2013. № 3 (63). С. 122-132.

20.Семененко О. М. Методика воєнно-економічного оцінювання результатів виконання заходів програм розвитку Збройних Сил України за плановий рік. Збірник наукових праџь Центрального науково-дослідного інституту Збройних Сил Украӥни 2010. № 3(53). С. 78-93.

21. Дєнєжкін М. М. Ефективність планування та виконання програм і планів розвитку Збройних Сил України. Сuстеми озброєння і військова техніка. 2018. № 2(54). С. 115-120. https://doi.org/10.30748/soivt.2018.54.16.

22. Романченко І. С., Богданович В. Ю., Дєнєжкін М. М., Крикун П. М., Стан і перспективи розвитку системи оборонного планування в Збройних Силах України. Наука і оборона. 2017. № 1. С. 25-30.

23. Дєнєжкін М. М., Ткач М. Я. Погляд на оцінювання здатності військових формувань Збройних Сил України виконати поставлені завдання з використанням принципів і правил країн-членів НАТО. Наука і техніка Повітряних Сил Збройних Сил України. 2021. № 3(44). С. 18-25. https://doi.org/10.30748/nitps.2021.44.02.

24. Дєнєжкін М. М. Шляхи вирішення проблемних питань планування розвитку спроможностей військових формувань Збройних Сил України. Наука і техніка Повітряних Сил Збройних Сил Украӥни. 2021. № 1(42). С. 28-33. https://doi.org/10.30748/nitps.2021.42.03.

25. Леонтьєв О. Б., Науменко М. В. Напрями удосконалення науково-методичного апарату обгрунтування основних напрямів розвитку системи озброєння авіації Повітряних Сил Збройних Сил України. Наука $і$ техніка Повітряних Сил Збройних Сил України. 2020. № 3(40). С. 69-78. URL: https://doi.org/10.30748/nitps.2020.40.08.

26. Дроздов С. С. Леонтьєв О. Б., Науменко М. В. Формалізовані критерії раціональності програми розвитку системи озброєння тактичної авіації Повітряних Сил Збройних Сил України на довгостроковій перспективі (прогнозованій) загрозі. Збірник наукових праџьь Харківського нациінального університету Повітряних Сил. 2020. № 3(65). С. 13-24. https://doi.org/10.30748/zhups.2020.65.02.

27. Дроздов С. С., Леонтьєв О. Б., Науменко М. В. Методичний підхід до розв'язування математичної задачі синтезу раціональної програми розвитку системи озброєння тактичної авіації на основі критерію мінімізації фінансових витрат за умови досягнення необхідних бойових спроможностей. Наука і техніка Повітряних Сил Збройних Сил Украӥни. 2020. № 4(41). C. 54-63. https://doi.org/10.30748/nitps.2020.41.06.

28. Леонтьєв О. Б., Науменко М. В. Методичний підхід до розв'язування математичної задачі синтезу раціональної програми розвитку системи озброєння тактичної авіації на основі критерію досягнення максимально можливого рівня бойових спроможностей за умови обмеженого ресурсного забезпечення. Наука і техніка Повітряних Сил Збройних Сил Украӥни. 2021. № 1(42). С. 50-60. URL: https://doi.org/10.30748/nitps.2021.42.06.

29. Візія Повітряних Сил 2035. Вінниця : Командування Повітряних Сил Збройних Сил України. 2020. 42 с.

30. GDP (constant 2015 US\$) - Ukraine. URL: https://inlnk.ru/PmgaPN (дата звернення: 01.11.21).

31. Два сценарії розвитку української економіки: трендовий і цільовий. URL: https://strategy.uifuture.org/dvascenar\%D1\%96i-rozvitku-ukrainskoi-ekonom\%D1\%96ki.html (дата звернення: 01.11.21).

32. Макроекономічний прогноз на 2022-2024 роки. Міністерство фінансів Украӥни : веб-сайт. URL: https://mof.gov.ua/uk/macroeconomic_forecast_for_2020-2022-379 (дата звернення: 01.11.21).

33. Про оборонні закупівлі : Закон України від 17 лип. 2020 p. № 808-IX. URL: https://zakon.rada.gov.ua/laws/show/808-20\#Техt (дата звернення: 01.11.21).

34. Бюджетний кодекс України. Верховна Рада України : веб-сайт. URL: https://zakon.rada.gov.ua/laws/show/245617\#Tеxt (дата звернення: 01.11.21).

35. Про затвердження Порядку організації та здійснення оборонного планування в Міністерстві оборони України, Збройних Силах України та інших складових сил оборони : Наказ Міністерства оборони України від 20 груд. 2020 р. № 484. URL: https://zakon.rada.gov.ua/laws/show/z0196-21\#Text (дата звернення: 01.11.21).

36. “Біла книга - 2019-2020. Збройні Сили України”. Київ : МОУ, 196 с. URL: https://www.mil.gov.ua/content/files/ whitebook/WB_2020_FINAL.pdf (дата звернення: 01.11.21).

37. “Біла книга - 2018. Збройні Сили України”. Київ : MOУ, 2019. 172 c. URL: https://www.mil.gov.ua/content/files /whitebook/WB-2018.pdf (дата звернення: 01.11.21).

38. “Біла книга - 2017. Збройні Сили України” Київ : MOУ, 2018. 152 c. URL: https://www.mil.gov.ua/content/files /whitebook/WB-2017.pdf (дата звернення: 01.11.21)

39. “Біла книга - 2016. Збройні Сили України” Київ : МОУ, 2017. 113 c. URL: https://www.mil.gov.ua/content/files /whitebook/WB_2016.pdf (дата звернення: 02.11.21).

40. “Біла книга - 2015. Збройні Сили України” Київ : MOУ, 2016. 105 c. URL: http://www.compancommand.com/ _ld/0/45_WB_2015.pdf (дата звернення: 01.11.21).

41. "Біла книга - 2014. Збройні Сили України” Київ : MOУ, 2015. 85 с. URL: https://www.mil.gov.ua/content/files/ whitebook/WB_2014.pdf (дата звернення: 01.11.21).

42. Оборонний бюджет у 2022 році виросте на 10\%, ДОЗ стане більшим на третину. Defense Express : веб-сайт. URL: https://inlnk.ru/3ZD99j (дата звернення: 02.11.21). 
43. Перелік державних цільових програм, які виконуються в межах бюджетної програми у 2021 році. Верховна Рaда України : веб-сайт. URL: https://itd.rada.gov.ua/billInfo/Bills/pubFile/265646 (дата звернення: 01.11.21).

44. Оборонний бюджет у 2022 році виросте на 10\%, ДОЗ стане більшим на третину. Defense Express : веб-сайт. URL: https://inlnk.ru/agwppz (дата звернення: 02.11.21).

45. Владимир Зеленский подписал закон о государственном бюджете Украины на 2022 год. Официальное интернет-представительство : веб-сайт. URL: https://www.president.gov.ua/ru/news/volodimir-zelenskij-pidpisav-zakon-proderzhavnij-byudzhet-u-71993 (дата звернення: 02.11.21).

46. Ukraine Growth Study Final Document. The Worldbank : web site. URL: https://documents1.worldbank.org/curated/en/543041554211825812/pdf/Ukraine-Growth-Study-Final-Document-Faster-Lastingand-Kinder.pdf (accessed 01.11.21).

47. World Bank, Poverty \& Equity and Macroeconomics. The Worldbank : web site. URL: https://pubdocs.worldbank.org/en/226251492011114754/mpo-ukr.pdf (accessed 02.11.21).

48. Индекс инфляции 2022 в Украине. Минфин : веб-сайт. URL: https://index.minfin.com.ua/economy/index/inflation/ (дата звернення: 02.11.21).

49. Inflation, consumer prices (annual \%). The Worldbank : web site. URL: https://data.worldbank.org/indicator/FP.CPI.TOTL.ZG (accessed 02.11.21).

50. Теорія озброєння. Науково-технічні проблеми та завдання. Т. 4. Воєнно-технічна політика провідних країн світу: монографія / Чепков І. Б. та ін. Київ : Вид. дім Дмитра Бураго, 2016. 388 с.

51. Чепков І. Б., Зубарєв В. В., Борохвостов В. К. Теорія озброєння. Науково-технічні проблеми та завдання. Т. 6. Воєнно-економічний аналіз життєвого циклу озброєння та військової техніки: теоретико-методологічні засади: монографія. Київ : Вид. дім Дмитра Бураго, 2018. 475 с.

52. Connolly R., Boulègue M. Russia's New State Armament Programme Implications for the Russian Armed Forces and Military Capabilities to 2027. London : Chatham House, 2018. 42 p. URL: http://surl.li/bhvhh (дата звернення: 01.11.21).

53. Леонтьєв О. Б., Науменко М. В. Методика прогнозування вартості життєвого циклу парків альтернативних типів нових багатоцільових літаків, як основних носіїв бойових спроможностей тактичної авіації. Збірник наукових праць Харківського начіонального університету Повітряних Сил. 2021. № $2(68) . \quad$ С. $16-25$. https://doi.org/10.30748/zhups.2021.68.02.

54. Леонтьєв О. Б., Науменко М. В. Методичний підхід до прогнозування витрат на оновлення та використання парку озброєння та військової техніки. Військово-технічний збірник. 2021. № 24. С. 37-45. https://doi.org/10.33577/23124458.24.2021.37-45.

55. Леонтьєв О. Б., Науменко М. В. Методика оцінювання альтернативних типів багатоцільових тактичних літаків для оновлення парку тактичної авіації Повітряних Сил Збройних Сил України. Social development \& Security. 2021 . № 3. C. 3-19. https://doi.org/10.33445/sds.2021.11.3.1.

Надійшла до редколегї 05.11.2021

Схвалена до друку 14.12.2021

\section{Відомості про автора:}

Науменко Марина Володимирівна

кандидат технічних наук старший науковий співробітник докторант

Харківського національного університету

Повітряних Сил ім. І. Кожедуба,

Харків, Україна

https://orcid.org/ 0000-0002-1216-9263
Information about the author:

Maryna Naumenko

$\mathrm{PhD}$ in Engineering Senior Researcher

Doctoral Candidate

of Ivan Kozhedub Kharkiv

National Air Force University,

Kharkiv, Ukraine

https://orcid.org/ 0000-0002-1216-9263

\title{
МЕТОДИЧЕСКИЙ ПОДХОД К ОЦЕНИВАНИЮ ВОЗМОЖНОСТИ РЕАЛИЗАЦИИ ПРОГРАММЫ ОБНОВЛЕНИЯ ПАРКА САМОЛЕТОВ ТАКТИЧЕСКОЙ АВИАЦИИ НА ЭТАПЕ ЕЕ СИНТЕЗА ПРИ ОГРАНИЧЕННЫХ ФИНАНСОВЫХ ВОЗМОЖНОСТЯХ ГОСУДАРСТВА
}

\author{
М.В. Науменко
}

Предложен методический подход к количественной оченке баланса между необходимыми затратами ресурсов и имеюшимися в государстве финансовыми ресурсами, которые могут быть выделены для реализации синтезированных вариантов программы развития системы вооружения и военной техники тактической авиации на средне- и долгосрочной перспективе. Данный методический подход, в зависимости от варианта выбора стратегии развития системь вооружения тактической авиачии, предназначен для оценки возможности реализации рационального варианта программы, синтезированного на основе решения математической задачи оптимизации в обратной постановке, а также для формирования элементов системы ограничений в формализованном критерии рациональности при выборе стратегии развития парков самолетов тактической авиаџии по приобретению ею необходимых возможностей в минимально возможное время и в формализованном критерии рациональности - при выборе стратегии по максимальному наращиванию способностей тактической авиаџией при ограниченном финансировании развития системы вооружения и военной техники. Поскольку финансирование программы перевооружения тактической авиации, скорее всего, будет осуществляться на средства Государственного бюджета Украины, в предложенном методическом подходе к оченке воз- 
можности реализации такой программы предлагается опираться на нормативно-правовую базу Украины, регламентируюшую объемы финансирования Сектора безопасности и обороны, и статистические данные по имеющемуся распределению средств на потребности Вооруженных Сил Украины по видам и направлениям финансирования, а также результаты анализа мирового опыта финансирования такого рода программ. Прогноз финансовых показателей на заданной глубине планирования развития системь вооружения и военной техники тактической авиации, характеризующих объемы иелевого финансирования затрат на развитие, закупку, модернизацию и ремонт вооружения, военной техники, средств и оборудования, предлагается строить на использовании статистического материала для финансирования перевооружения тактической авиации, накопленного в ретроспективе и данных прогноза Всемирного банка о росте ВВП Украины на средне- и долгосрочной перспективе. Выявление на этапе синтеза несоответствия нужного финансового ресурса тому, который ожидаемо сможет быть обеспечен государственным финансированием, предоставляет возможности для своевременного поиска альтернативных путей приобретения необходимых возможностей или дополнительных источников финансирования, что будет способствовать предотвращению излишних затрат ресурсов и времени для приобретения необходимого уровня способностей тактически.

Ключевые слова: тактическая авиация, стратегия развития, финансирование, прогноз.

\section{A METHODOLOGICAL APPROACH TO ASSESSING THE POSSIBILITY OF IMPLEMENTING THE PROGRAM OF TACTICAL AVIATION FLEET RENEWAL AT THE STAGE OF ITS SYNTHESIS WITH LIMITED FINANCIAL POSSIBILITIES OF THE STATE}

\section{Naumenko}

A methodical approach is proposed to quantify the balance between the necessary expenditure of resources and the financial resources available in the state that can be allocated for the implementation of synthesized options for the development program for the weapon system and military equipment of tactical aviation in the medium and long term. This methodological approach, depending on the option of choosing a strategy for the development of a tactical aviation weapon system, is designed to assess the possibility of implementing a rational version of the program, synthesized on the basis of solving a mathematical optimization problem in the reverse formulation, as well as to form elements of a system of constraints in a formalized criterion of rationality when choosing a strategy development of fleets of tactical aviation aircraft to acquire the necessary capabilities in the shortest possible time and in a formalized criterion of rationality - when choosing a strategy for maximizing the capabilities of tactical aviation with limited funding for the development of the weapon system and military equipment. Since the financing of the tactical aviation rearmament program will most likely be financed from the State Budget of Ukraine, the proposed methodological approach to assessing the possibility of implementing such a program is proposed to be based on the legal framework of Ukraine, which regulates the amount of funding for the Security and Defense Sector, and statistical data on the available distribution of funds for the needs of the Armed Forces of Ukraine by type and direction of funding, as well as the results of the analysis of world experience in financing such programs. The forecast of financial indicators at a given depth of planning for the development of the system of weapons and military equipment of tactical aviation, characterizing the volume of targeted financing of the costs of development, purchase, modernization and repair of weapons, military equipment, facilities and equipment, is proposed to be based on the use of statistical material for financing the rearmament of tactical aviation, accumulated in retrospect and the data of the World Bank forecast on Ukraine's GDP growth in the medium and long term. Identification at the stage of synthesis of the discrepancy between the required financial resource and that which can be expected to be provided by public funding provides opportunities for the timely search for alternative ways to acquire the necessary capabilities or additional sources of funding, which will help prevent unnecessary expenditure of resources and time to acquire the required level of abilities tactically.

Keywords: tactical aviation, development strategy, financing, forecast. 